\title{
KAJIAN KADAR CHOLINESTERASE DALAM DARAH OPERATOR FOGGING MENURUT MASA KERJA, LAMA PAPARAN DAN PENGGUNAAN APD DI KOTA SURABAYA \\ Gani Agustoini, Setiawan, Marlik
}

\begin{abstract}
Surabaya city are scarlatina endemis area with the number of cases who are still high. Last three years data, showing patient of scarlatina totality 3.379 people in $2010,1.008$ people in 2011 and 1.091 people in 2012. Highest of scarlatina cases purpose in long exposure frequency pesticides to do spraying on operators fogging the longer close fitting. Operators fogging have a risk exposure of pesticides. This will be worse if not supported by the use of APD good and right. This research aimed to assess the duration work, long exposure and using of safety aparatus with cholinesterase levels on operators fogging

The kind of research used is research that is both a moment of observational (cross sectional). Data collecting by means of observation and spread a questionnaire. An population research is the fogging guidance operator service and control a vector department of health city surabaya in the city of surabaya with the number is 70 operators fogging by samples 41 responden taken in simple random sampling. Data next presented in table form and analyzed in descriptive.

The results showed that the majority of operators fogging over 3 years $70.7 \%$, overall long exposure $(\mathbf{1 0 0} \%)$ of less than 5 hours and as much as $78.0 \%$ operator fogging wear APD but not complete $(100 \%)$ with normal cholinesterase ( $75-100 \%$ )

With see the result of this research was then suggested to operators of the pesticide fogging should reduce exposure by them self, no smoking and eat / drink after if pesticides contact and always for washing hands using soap with clean water.
\end{abstract}

\section{Keyword : Cholinesterase}

\section{PENDAHULUAN}

Kesehatan kerja (occupational health) merupakan bagian dari kesehatan masyarakat yang berkaitan dengan semua pekerjaan yang berhubungan dengan faktor potensial yang mempengaruhi kesehatan pekerja (dalam hal ini operator fogging). Salah satu faktor potensial yang dapat menimbulkan terjadinya gangguan kesehatan pada tenaga kerja adalah adanya bahaya di tempat kerja (keracunan). Bahayabahaya yang terdapat di lingkungan kerja dapat dibagi menjadi tiga yaitu; bahaya fisik (terpeleset, terjatuh, debu), bahaya mikrobiologi (virus, parasit, bakteri, jamur) dan bahaya kimiawi (zat kimia dalam bentuk cair, padat dan gas) (Siswanto, 1991). Salah satu jenis bahaya kimiawi yang berpotensi menimbulkan gangguan kesehatan adalah pestisida (Dalam Purwanti, 2009)

Pestisida yang banyak direkomendasikan untuk bidang pengendalian vektor penyakit adalah golongan organofosfat, karena golongan ini lebih mudah terurai di alam. Golongan organofosfat mempengaruhi fungsi syaraf dengan jalan menghambat kerja enzim cholinesterase, suatu bahan kimia esensial dalam mengantarkan impuis sepanjang serabut syaraf. Salah satu kegiatan yang berhubungan dengan pestisida adalah fogging.

fogging (pengasapan) adalah pengendalian vektor penyakit demam berdarah menggunakan alat fog dengan metode fogging. Prinsip kerja dari metode ini adalah mematikan serangga melalui sistem pernapasan bertujuan untuk membunuh nyamuk Aedes aegypti dewasa yang
Iolos dari pemberian bubuk abate yang akan memberikan knock down effect agar mata rantai penularan penyakit demam berdarah segera diputuskan.

Dinas Kesehatan Kota Surabaya merupakan unit controlling dari kegiatan fogging yang ada di dalam Kota Surabaya. Dinas Kesehatan Kota Surabaya memiliki cakupan wilayah kerja yaitu puskesmas yang terbagi menjadi 62 wilayah kerja yang tersebar di setiap kelurahan di 5 bagian wilayah Surabaya. Dalam 3 tahun terakhir, menunjukan jumlah penderita demam berdarah di Kota Surabaya sebanyak 3379 orang tahun 2010, 1008 orang tahun 2011 dan 1091 orang tahun 2012.

Tingginya kasus demam berdarah mengakibatkan frekuensi lama paparan dalam melakukan fogging semakin banyak dan penyemprotan juga akan semakin sering dilakukan seiring dengan program penanggulangannya. Operator fogging merupakan orang yang beresiko tinggi terhadap keracunan pestisida, apalagi jika tidak didukung dengan penggunaan APD (Alat Pelindung Diri) secara baik dan benar untuk tenaga penyemprot, sehingga memungkinan pestisida dapat masuk ke dalam jaringan tubuh, baik melalui kulit, mulut dan pernapasan. Keadaan seperti inilah yang kurang mendapat perhatian dan sering kali terabaikan.

\section{TUJUAN}

Untuk mengetahui kajian masa kerja, lama paparan dan penggunaan APD pada operator 
fogging dengan kadar cholinesterase dalam

darah di Kota Surabaya.

\section{METODE PENELITIAN}

Jenis Penelitian

Jenis penelitian ini adalah observasional yang bersifat sesaat (cross sectiona) Penelitian ini dilakukan di Kota Surabaya. Objek penelitian adalah operator fogging binaan Pelayanan dan
Pengendalian Vektor Dinas Kesehatan Kota Surabaya.

\section{Populasi dan Sampel}

Populasi pada penelitian ini adalah operator fogging binaan Pelayanan dan Pengendalian Vektor Dinas Kesehatan Kota Surabaya sebanyak 70 orang.

Dan untuk sampel di hitung dengan rumus :

$\mathrm{n}=\frac{N}{1+N\left(\mathrm{~d}^{2}\right)}$ Sehingga di dapatkan sampel sebanyak 41 orang

Teknik Pengambilan Sampel

Teknik pengambilan sampel yang dilakukan dengan cara simple random sampling dengan cara mengundi anggota populasi (Jottery technique) atau teknik undian. (Notoatmojo, 2005)

\section{hASIL PENELITIAN DAN PEMBAHASAN}

\section{a. Masa Kerja Menjadi Operator Fogging}

MASA KERJA OPERATOR FOGGING

DI KOTA SURABAYA

TAHUN 2013

\section{Analisis Data}

Hasil penelitian selanjutnya dianalisa secara deskriptif yang disajikan dalam bentuk narasi dan tabel.

\begin{tabular}{cccc}
\hline No & Masa Kerja & Jumlah & Persentase (\%) \\
\hline 1 & $<1$ tahun & 2 & 4,9 \\
\hline 2 & $1-3$ tahun & 10 & 24,4 \\
\hline 3 & $\geq 3$ tahun & 29 & 70,7 \\
\hline & Jumlah & $\mathbf{4 1}$ & $\mathbf{1 0 0}$ \\
\hline
\end{tabular}

Sebagian besar responden memiliki masa kerja lebih dari 3 tahun yaitu $70,7 \%$ (29 operator fogging) sehingga resiko mengalami keracunan pestisida besar. Menurut penelitian Sari (2012) menyatakan bahwa semakin lama masa kerja seseorang berhubungan dengan pestisida semakin lama juga kontak langsung pestisida dengan tubuh, sehingga kemungkinan untuk mengalami keracunan juga semakin besar untuk itu dianjurkan kepada operator fogging untuk memakai APD pada saat melakukan penyemprotan / fogging.

\section{b. Lama Paparan}

Tabel 2

\section{LAMA PAPARAN OPERATOR FOGGING} DI KOTA SURABAYA TAHUN 2013

\begin{tabular}{cccc}
\hline No & Lama Paparan & Jumlah & Persentase (\%) \\
\hline 1 & $<5 \mathrm{jam}$ & 41 & 100 \\
\hline 2 & $\geq 5 \mathrm{jam}$ & 0 & 0 \\
\hline & Jumlah & $\mathbf{4 1}$ & $\mathbf{1 0 0}$ \\
\hline
\end{tabular}

Berdasarkan hasil penelitian yang dilakukan menunjukkan bahwa dari 41 responden keseluruhan $(100 \%)$ melakukan penyemprotan kurang dari 5 jam. Dengan rincian waktu lamanya operator fogging melakukan penyemprotan rata - rata 2 - 3 jam dan paling lama 4 jam. Gejala keracunan pestisida organofosfat dan carbamat biasanya timbul setelah 4 jam kontak, tetapi bisa timbul setelah 12 jam. Lama waktu saat penyemprotan merupakan hal yang harus diwaspadai karena semakin lama operator fogging kontak dengan pestisida maka akan semakin besar kemungkinan mengalami keracunan. (Runia, 2008) 
Tabel 3

PENGGUNAAN APD OPERATOR FOGGING DI KOTA SURABAYA TAHUN 2013

\begin{tabular}{clcc}
\hline No & \multicolumn{1}{c}{ Penggunaan APD } & Jumlah & Persentase (\%) \\
\hline 1 & Memakai lengkap & 2 & 4,9 \\
\hline 2 & Memakai tetapi tidak lengkap & 32 & 78,0 \\
\hline 3 & Tidak memakai & 7 & 17,1 \\
\hline & Jumlah & $\mathbf{4 1}$ & $\mathbf{1 0 0}$ \\
\hline
\end{tabular}

Berdasarkan hasil penelitian menunjukkan bahwa sebagian besar operator fogging memenuhi kategori memakai APD tetapi tidak lengkap sebesar $78,0 \%$ (32 operator fogging). $\mathrm{Hal}$ ini disebabkan oleh operator fogging merasa tidak nyaman dan sudah menjadi kebiasaan jika kontak dengan pestisida tidak menggunakan APD. Sehingga pada saat kontak dengan pestisida dianggap hal yang tidak berbahaya. Sebagian besar operator fogging sudah mentaati peraturan dalam penggunaan APD tetapi untuk jenis APD tangan (sarung tangan) masih ada tenaga penyemprot yang tidak menggunakan dengan alasan tidak nyaman dan licin. Pestisida dapat mudah masuk melalui kulit, termakan lewat mulut, dan terhirup oleh saluran pernafasan yang sangat beresiko terhadap keracunan baik secara langsung maupun dalam jangka waktu yang cukup lama. Satu hal yang sering dilupakan oleh tenaga penyemprot (di negara tropis), umumnya adalah contact poison. Oleh sebab itu, route of entry melalui kulit sangat efektif. Apalagi jika ada kelainan pada kulit dan atau bersama keringat, penyerapan pestisida melalui kulit akan lebih efektif. Kejadian kontaminasi pestisida melalui kulit merupakan kontaminasi yang paling sering terjadi, meskipun tidak seluruhnya berakhir dengan keracunan akut. Lebih dari $90 \%$ kasus keracunan diseluruh dunia disebabkan oleh kontaminasi lewat kulit. Keracunan karena partikel pestisida atau butiran semprot terhisap melalui hidung merupakan kasus terbanyak nomor dua setelah kontaminasi kulit. Oleh karena itu, perlu dilakukan pembinaan dan pengawasan lebih lanjut dalam menggunakan APD. Karena mengingat pentingnya fungsi penggunaan APD tersebut yaitu untuk mengurangi / mencegah masuknya pestisida kedalam jaringan tubuh (Asyim, 2009).

\section{d. Kadar Cholinesterase Dalam Darah Pada Operator Fogging di Kota Surabaya Tabel 4 \\ KADAR ENZIM CHOLINESTERASE OPERATOR FOGGING DI KOTA SURABAYA TAHUN 2013}

\begin{tabular}{clcc}
\hline No & $\begin{array}{c}\text { Kadar Enzim } \\
\text { Cholinesterase }\end{array}$ & Frekuensi & Persentase (\%) \\
\hline 1 & Normal & 41 & 100 \\
\hline 2 & Keracunan ringan & 0 & 0 \\
\hline 3 & Keracunan sedang & 0 & 0 \\
\hline 4 & Keracunan berat & 0 & 0 \\
\hline & Jumlah & $\mathbf{4 1}$ & $\mathbf{1 0 0}$ \\
\hline
\end{tabular}

Berdasarkan tabel 4 dapat diketahui bahwa keseluruhan operator fogging $(100 \%)$ memiliki kadar cholinesterase normal yaitu $75 \%-100 \%$. Kadar cholinesterase dalam darah dipengaruhi oleh berbagai macam faktor. Faktor - faktor tersebut berasal dari dalam dan luar tubuh. Diantara faktor - faktor ada faktor dominan yang dapat mempengaruhi diantaranya:

\section{Usia}

Berdasarkan penelitian yang telah dilakukan rata - rata usia operator fogging adalah 35 tahun. $\mathrm{Hal}$ ini dikarenakan Dinas Kesehatan Kota Surabaya berpendapat bahwa usia berkaitan dengan kekebalan tubuh dalam mengatasi tingkat toksisitas suatu zat, semakin tua seseorang maka efektivitas sistem kekebalan di dalam tubuh akan semakin berkurang sehingga operator fogging yang usianya lebih dari 35 tahun tidak diperbolehkan melakukan fogging kembali.

2. Status gizi

Dinas Kesehatan Kota Surabaya mempunyai program pengendalian keracunan pestisida pada tenaga penyemprot / operator fogging binaannya dengan memberikan makan tambahan yang rutin setiap bulan dilaksanakan.

\section{Pengetahuan, sikap dan tindakan}

Pengetahuan, sikap dan tindakan dalam hal ini adalah penggunaan APD dan bahaya dari penggunaan pestisida. Pengetahuan operator 
fogging sangat mempengaruhi kadar cholinesterase. Pengetahuan tentang penggunaan APD dan bahaya pestisida dapat diperoleh baik melalui pendidikan formal dan informal. Pengetahuan merupakan faktor penting yang berpengaruh terhadap perilaku seseorang / kelompok untuk bertindak. Menurut Green, 1980 (dalam Purwanti) bahwa pengetahuan merpakan faktor predisposisi / juga disebut prefensi pribadi yang dibawa seseorang / kelompok ke dalam suatu pengalaman belajar, prefensi ini mendukung / menghambat perilaku sehat dalam setiap masalah. Faktor ini berpengaruh terhadap seseorang / sekelompok orang untuk bertindak. Dari hasil observasi masih ditemukan beberapa operator fogging yang merokok pada waktu sesudah penyemprotan, yang pada saat - saat tersebut mereka masih belum mencuci tangan / membersihkan diri dari bekas - bekas pestisida. Hal ini memungkinkan pestisida masuk ke dalam tubuh operator fogging dan kemungkinan mengalami keracunan semakin besar bila tidak adanya upaya pencegahan. Penelitian yang dilakukan. Purwanti (2009) menyatakan bahwa. ada hubungan antara kebiasaan merokok dengan kadar cholinesterase pada tenaga penyemprot. Hal ini sepele namun hendaknya operator fogging memperhatikan secara seksama tentang bahayanya untuk menimalisir terjadinya keracunan.

\section{Waktu penyemprotan}

Berdasarkan penelitian yang telah dilakukan rata - rata waktu penyemprotan yang dilakukan operator fogging adalah pada pagi hari atau sore hari. Ini dikarenakan operator fogging memperhatikan waktu aktif dari nyamuk Aedes Aegypthy.

\section{Frekuensi penyemprotan}

Operator fogging melakukan penyemprotan hanya ketika ditemukan kasus demam berdarah di suatu wilayah kerja. Penyemprotan / fogging dilakukan seiring dengan tindakan pemberantasan sarang nyamuk yang terdapat pada penyelidikan epidemiologi sebagai upaya untuk memutus mata rantai penularan penyakit demam berdarah. Dari penelitian yang telah dilakukan sebagian besar operator fogging melakukan penyemprotan sebanyak 2 - 3 kali dalam seminggu dan paling banyak sebanyak 4 kali. Penyemprotan / fogging ini tidak dilakukan secara terus - menerus selama setiap hari, sehingga paparan pestisida yang diterima operator fogging terputus - putus. Frekuensi penyemprotan dapat dilihat dari banyaknya kasus demam berdarah per bulan disuatu wilayah kerja.

\section{Pembinaan dan pengawasan}

Pembinaan dan pengawasan yang dilakukan oleh Dinas Kesehatan Kota Surabaya adalah upaya untuk meminimalisir terjadinya keracunan akibat pestisida. Salah satu upaya yang rutin dilaksanakan adalah dengan melakukan pemeriksaan kadar cholinesterase operator fogging secara rutin setahun sekali. Selain itu adanya pemberian makanan tambahan seperti susu dan suplemen setiap sebulan sekali secara berkala.

\section{KESIMPULAN DAN SARAN \\ Kesimpulan}

1. Sebagian besar operator fogging mempunyai masa kerja lebih dari 3 tahun yaitu $70,7 \%$.

2. Keseluruhan operator fogging (100\%) mempunyai lama paparan dengan pestisida selama kurang dari 5 jam.

3. Sebagian besar operator fogging memakai APD tetapi tidak lengkap yaitu $78,0 \%$.

4. Kadar cholinesterase pada operator fogging adalah $100 \%$ normal ( $75 \%-100 \%$ ).

\section{Saran}

1. Bagi instansi terkait sebaiknya lebih meningkatkan pengawasan terhadap operator fogging pada waktu melakukan fogging dan penyuluhan tentang penggunaan APD yang baik dan benar sesuai dengan persyaratan tenaga penyemprot untuk meminimalisir terjadinya keracunan akibat pestisida

2. Bagi masyarakat khususnya operator fogging hendaknya mengurangi pemaparan pestisida dengan cara menggunakan alat pelindung diri meliputi alat pelindung tangan (sarung tangan) dan alat pelindung pernapasan, menghindari kegiatan merokok maupun makan / minum jika sesudah melakukan kontak langsung dengan pestisida, dan selalu membiasakan diri untuk mencuci tangan dengan air bersih dan menggunakan sabun.

3. Bagi peneliti lain perlu diadakan penelitian lanjutan mengenai faktor - faktor lain yang dapat mempengaruhi kadar cholinesterase yang berasal dari dalam tubuh seperti status gizi serta dilakukan pembinaan dan pengawasan penyemprotan pada operator fogging seperti program penanggulangan keracunan pestisida

\section{DAFTAR RUJUKAN}

Atmosoeharjo, 1991. Suatu Upaya Pengendalian Pestisida Melalui Pendekatan IImu Pengetahuan dan Teknologi. Surabaya: FKM UNAIR

Afriyanto, 2008. Kajian Keracunan Pestisida Pada Petani Penyemprot Cabe Di Desa Candi Kecamatan Bandungan Kabupaten Semarang. Semarang: Universitas Diponegoro Semarang.

Anizar, 2009. Teknik Keselamatan dan Kesehatan Kerja Di Industri. Yogyakarta: Graha IImu 
Asyim, R.B., 2009. Hubungan Antara Pemakaian Alat Pelindung Diri dengan Aktifitas Cholinesterase Darah - Surabaya: Politeknik Kesehatan Depkes Surabaya.

Depkes RI, 1992. Pemeriksaan Cholinesterase Darah dengan Tintometer Kit. Jakarta: Ditjen PPM \& PLP.

Djojosumarto, Panut, 2008. Pestisida dan Aplikasinya. Jakarta: Agromedia Pustaka.

Dinas Kesehatan Provinsi Jawa Timur, 2011. Laporan pemantauan pajanan pestisida pada penjamah pestisida. Bidang pengendalian penyakit dan masalah kesehatan.

Iskandar, Adang. 1985. Pemberantasan Serangga dan Binatang Pengganggu. Indonesia. Proyek Pengembangan Pendidikan Tenaga Sanitasi Pusat.

Keppres RI Nomor 22 Tahun 1993 Tentang Penyakit Yang Timbul Karena Hubungan Kerja.

Keputusan Menteri Tenaga Kerja RI NO. KEP.

187/ MEN/ 1999 Tentang Pengendalian

Bahan Kimia Berbahaya Di Tempat Kerja.

Kepmenkes Nomor 1350/ MENKES/ SKI XII/ 2001 Tentang Pestisida.

Notoatmodjo, Soekidjo, 2010. Metodologi Penelitian Kesehatan. Jakarta, PT Rineka Cipta: 35-187.

Peraturan Pemerintah No.7 Tahun 1973 Tentang Pengawasan Atas Peredaran Penyimpanan dan Penggunaan Pestisida.
Peraturan Menteri Tenaga Kerja RI Nomor: PER03/ MEN/ 1986 Tentang Syarat-syarat Keselamatan dan Kesehatan Di Tempat Kerja Yang Mengelola Pestisida.

Purwati, Ani, 2009. Hubungan Antara Penggunaan Alat Pelindung Diri (APD) Dengan Kadar Cholinesterase Darah Pada Tenaga Penyemprot. Surabaya: Politeknik Kesehatan Depkes Surabaya.

Peraturan Menteri Tenaga Kerja dan Transmigrasi RI Nomor Per. 08/ MEN/ VII/ 2010 Tentang Alat Pelindung Diri.

Riduwan, 2007. Skala Pengukuran Variabe/variabel Penelitian. Bandung: Alfabeta.

Runia, Yodenca Assti, 2008. Faktor - Faktor Yang Berhubungan Dengan Keracunan Pestisida Organofosfat Dan Carbamat Dan Kejadian Anemia Pada Petani Hortikultura. Magelang: Universitas Dipenogoro.

Siswanto, A., 1991. Pestisida. Balai Hiperkes dan Keselamatan Kerja Jawa Timur. Departemen Tenaga Kerja.

Sari, Lian Ratna, 2012. Faktor Yang Mempengaruhi Terjadinya Keracunan Pestisida Pada Petani. Surabaya: Politeknik Kesehatan Kemenkes Surabaya.

Wanodya, Endah, 2011. Hubungan Antara Masa Kerja, Lama Paparan dan Kelengkapan $A P D$ dengan Kadar Cholinesterase Dalam Darah. Surabaya: Politenik Kesehatan Kemenkes Surabaya. 